Introduction

\title{
Music and the emotions of medievalism: The quest for identity
}

\section{Helen Dell}

School of Culture and Communication, University of Melbourne, Melbourne, VIC, Australia.

postmedieval: a journal of medieval cultural studies (2019) 10, 411-422.

https://doi.org/10.1057/s41280-019-00147-7

In this special issue my co-editors Andrew Lynch and Elizabeth Randell Upton and I set ourselves a task whose complexity became more apparent as we proceeded. Writing this introduction, the task of considering the three components of our title - music, emotion, medievalism - in their various interrelations has been challenging, while at the same time convincing me of the value of scrutinizing them together.

Within the humanities, music has, until quite recently, been largely neglected in the study of medievalism. As a sounding art, it may have seemed less familiar in a field initially devoted more to sight-oriented activities, although it has been very much in evidence in a range of medievalist pursuits. Films, fiction, performances, recordings, and online games have created or adapted a range of musical tropes or their literary evocations that have become indissolubly associated with the 'medieval.' Possibly, the relative inattention music has received in medievalism studies is owing, as Claudia Gorbman noted, to the fact 
that film music tends to 'mask its own insistence and saw away in the backfield of consciousness' (Gorbman, 1987, 1). Game players and film audiences may feel the results without noticing how they are produced. But trained musicologists, tuned to an awareness of music, with its narrative, ideological, and emotional implications, are able to notice and to draw these implications into the foreground. Since the early years of the present century, musicology has contributed significantly to the concept of medievalism, though not initially under that title. Musicologists' work, perhaps as a result, did not receive the attention it warranted within the humanities. Karen Cook, Susan Fast, John Haines, Annette Kreutziger-Herr, Daniel Leech-Wilkinson, Elizabeth Randell Upton, Kirsten Yri, and Nick Wilson, among others, have produced much valuable work for students of medievalism.

A little more recently the gulf between medievalism in music on the one hand and the humanities on the other has begun to be bridged from the other side. Authors and editors have realized that music cannot be excluded when medievalism is the subject of enquiry - all the more so when the emotional aspects of medievalism are in question, as in fact they always are. As David Matthews affirms: "Medievalism" (however it is defined) is always bound up, necessarily and intimately, with emotional responses to the premodern past' (Matthews, 2018, 209).

Essay collections on medievalism have been including chapters on music for a decade and more. In 2007, David W. Marshall edited Mass Market Medievalism, which includes three chapters devoted to musical medievalism. Bettina Bildhauer and Anke Bernau's Medieval Film (2009) has a chapter on music in medievalist movies. In Medievalisms (2013), Tison Pugh and Angela Jane Weisl devote part of a chapter to recent performances of medieval and medievalinspired music. There is a chapter on neo-medieval music in The Middle Ages in Popular Culture, edited by Helen Young (2015). A music chapter is included in the Cambridge Companion to Medievalism (2016), edited by Louise D'Arcens. More recently, three essays were brought together in the final section of Studies in Medievalism: Authenticity, Medievalism, Music XXVI (2018), edited by Karl Fugelso. Ruth Barrett-Peacock and Ross Hagen's essay collection, Medievalism and Metal Music Studies: Throwing Down the Gauntlet, was published in May 2019. The Oxford Handbook on Music and Medievalism, edited by Stephen C. Meyer and Kirsten Yri, forthcoming in 2019, neatly embeds the association in its title. Some of the names associated with these writings are Ruth BarrettPeacock, Alana Bennett, James Cook, Karen M. Cook, Helen Dell, Ross Hagen, Paul Hardwick, Alexander Kolassa, Aleks Pluskowski, Tison Pugh, Simon Trafford, Alison Tara Walker, Angela Jane Weisl, Adam Whittaker, and Kirsten Yri.

Our issue adds to this expanding conversation, with new work from both musicologists and literary scholars. Our three medieval musicologists, Karen Cook, Elizabeth Randell Upton, and Kirsten Yri, are also working on the 
broader questions of medievalism, that is, on questions of how the 'medieval' and its music have been invented, modified, received, interpreted, felt, and understood, enabling them to elucidate for the non-musically trained the various musical means by which the 'medieval' is transmitted in different genres. Of particular relevance in this issue is their understanding of the emotional pull of music and how it can guide or manipulate the listener.

On the literary side are three scholars who combine research in the humanities with a love for and experience of music as performers, listeners, students, and teachers: Louise D’Arcens, Helen Dell, and Andrew Lynch. There are, however, no strict demarcation lines between the essays, an indication, I believe, that the conversation has now spread across what once seemed an impassable disciplinary divide. This is also true of the two 2019 book collections mentioned above.

Perhaps one could say that (as in my bridge metaphor), it might still make a difference to our mode of writing which side we start out from. Our three musicologists have tended to begin with sound and then work outwards to more general insights into medievalism and the emotions it arouses. The humanities trio in the collection have tended to work more from the side of words written about music or words evoking music or drawing on its metaphoric power, whether in fiction or argument. And it must be remembered that words heard, in sound or in imagination, also have their music - in emphasis, in timbre, in intonation, in all of which emotion plays a part, transferred from speaker to listener.

For the musicologists, Elizabeth Randell Upton's essay discusses how repetition in music, the backbone of medieval secular and liturgical song as it is for popular and folk song today, has been routinely ignored by composers, critics and musicologists brought up on classical music:

Repetition in song form, either popular or medieval, has not often been discussed, perhaps because it seems so straightforward and simple an element. But simplicity should not imply insignificance.

Upton responds to this scholarly neglect in her discussion of a song by Bob Dylan, 'Tangled Up in Blue,' modeled on Guillaume de Machaut's fourteenthcentury ballade form; Upton demonstrates how an accomplished and inventive singer/composer, by exploring the 'subtle medievalism' of form, can bring out the play of repetition and difference in a strophic song.

Kirsten Yri has written on the quixotic experiment by Rondellus, an Estonian medieval and Renaissance ensemble, to produce an album of songs by heavy metal band Black Sabbath, translated into Latin and using medievalist performance practices. The changes include abandoning electric for acoustic instruments - 'fiddles, organistrum, recorder, and lute [with] muted onsets, a much narrower dynamic range, and thinner timbres than electric guitars and basses' - and using trained, refined voices to replace the typical heavy metal 
1 The aesthetic emotions can be as turbulent as any. See Paul J. Silvia on some of the less-discussed aesthetic emotions, where he examines 'knowledge emotions such as interest, confusion, and surprise; hostile emotions such as anger and disgust; and self-conscious emotions such as pride, shame, and embarrassment' (Silvia, 2009, 48).

2 Internal quotation from Gorbman (1987). vocal snarls and screams. Such a metamorphosis, Yri suggests, using the terminology of Monique Scheer, translates the language of 'anger, aggression, and pain, viewed as beyond human control and positioned as largely "physical" and "exterior" into the language of "contentedness and reflection, carry[ing] little visual bodily expression or gesture, and [...] typically received as intellectual and "interior."

In this context, to medievalize music is to raise and refine it aesthetically and emotionally. As I think Yri assumes here, the aesthetic response is not separable from the emotional. ${ }^{1}$ Nor, for this reason, can the aesthetic response be disinterested. Music in particular has profound emotional effects on the listener, however they are theorized. These effects, sometimes unconscious, are implicated in various attitudes and agendas and erupt into arguments whose force cannot be understood unless the depth of emotional engagement is taken into account. And the reverse is also true: one's attitudes and agendas are implicated in the way one hears and receives music. Music creates an emotional hotspot on many levels.

Rondellus's 'editorial process' constitutes a reversal of the typical trajectory by which we progress from the barbaric Middle Ages to the civilized modern era. Differences in instrumental and vocal timbre, like those between Black Sabbath and Rondellus, communicate perfectly which 'medieval' is in question in any given context, without the medium of words. The word 'medieval' is flexible enough to cope with a range of implications: positive, negative, or oscillating between the two. Yri's essay reflects the oscillating nature of medievalism by exploring the alternative forms it takes in the work of these two medievalist music groups.

As Karen Cook notes in her essay, such oscillations are ubiquitous in medievalism. Music provides copious illustrations:

[Medieval] stereotypes have permeated Western culture since the Middle Ages themselves: the medieval past is, on the one hand, pure, tranquil, simple, religious. [...] On the other hand, it was barbaric, permeated by violence, torture, and inquisition, primitive and superstitious. [...] Through supporting such attributes or emotional states, medievalist musical tropes took on a sort of bifurcated polyvalence, such that the same sound can act as a 'connotative cue' [for a particular meaning and also its inverse] (Gorbman, 1987, 5). ${ }^{2}$

Thus, as Cook elaborates, in her section, 'The bell,' a sound may create 'divided emotional states: on the one hand tranquility, "joy, peace, or victory," on the other "something sinister." These differences depend on the sound's position within the narrative and in the player's situation, since 'the player's emotions can and will change depending on their familiarity with the game and their own success at achieving their goals.'

Cook uses a form of Topic Theory, that is, 
the analysis of how certain musical figures become saturated with and therefore convey extra-musical meanings. Unlike the Western instrumental genres most often analyzed in topic theory, though, the medievalist tropes I discuss here have been aligned with explicit narratives constructed through visual, textual, musical, and other descriptive means. As such, their array of possible emotive meanings becomes both clarified and reified as they appear in a given context.

Narrative and emotional context is thus all-important in modifying the effects of medievalist musical cues in game-playing.

Nonetheless, Cook argues, in spite of the polyvalence of certain musical sounds, some musical tropes are difficult to detach from their dominant associations:

We cannot change how certain musical sounds have been associated with medievalist contexts in the past, nor [...] completely eliminate their medievalist overtones from our aural memories. Yet when we continue to rely on those sounds to create or reinforce the emotional states with which they have become so closely linked, I suggest that we inadvertently imbue the new context with a mythological [...] idea of the medieval past. For example, by almost exclusively using musical tropes clearly linked to the Christian church to depict the medievalist, do we not imply that those sounds alone can represent the past, and thus imply that that is because the past was solely, wholly Christian?

\section{Medievalism and identity}

Cook alludes here to what has turned out to be a vital question in this issue and, I believe, in medievalism studies generally: the question of identity for the medievalist player, listener, viewer, reader, academic, or enthusiast of any kind. (In the academy we study medievalism, but that does not mean we are immune to its influence.) Our essays demonstrate, some more than others, that questions of identity lie at the heart of medievalism and are a potent driving force in the forms it takes and in the reactions it produces. We project something of the selves we wish to be seen in our medievalist pursuits, to those by whom we wish to be recognized. A glance at Facebook or a range of forums, online and off, offers examples of these projections.

Music plays a significant role in the establishment and maintenance, sometimes the evolution, of an identity. The quest for identity can also be seen as a factor in determining which particular associations remain dominant in medievalist music. As Cook demonstrates, in Western performances, recordings, study, games, and films, musical sounds with their associations have played a significant role in the emotionally charged interior maps that those of European 
descent have drawn of the medieval world. Cook's example centralizes a homogeneously white and Christian Europe within a boundary beyond which lurks the 'other' little-known, alien world to be reckoned with. When these already loaded musical associations are re-enforced by similar narrative and visual cues, they have the capacity to reach beyond the fictional universe and create havoc in the world we share. That shared world is, in any case, so heavily overwritten by a range of assumptions and their concomitant emotions that it is rendered virtually invisible.

On the literary side too, as in my essay, music plays a significant role in providing (or withholding) answers to the questions of identity - who am I? who are we? who is the other? what is my relation to the other? what distinguishes me from the other? - by which we construct ourselves and those we deem 'other,' shoring up the differences required to sustain an identity constructed on the basis of binary opposition. Other questions naturally follow: who is my friend? who is my enemy? or perhaps, as demonstrated in D'Arcens's and Lynch's essays: how can ancient enmities be healed and feuds ended? Yri's essay reflects the oscillating aspect of medievalism by exploring the alternative forms of identity it offers in the work of two medievalist music groups: that exemplified by the 'exterior' emotional expression of Black Sabbath - raw, bodily, and unrestrained - and the more compressed and restrained 'interior' expression of Rondellus.

These questions of identity may be asked at a personal, group, or national level or at an even broader level, for instance that invoked by the terms 'East' and 'West' in D'Arcens's essay. In my essay, the distinctness of national musical traditions is recruited as the key to national identity, just as, in Cook's essay, the bell sustains an atmosphere of medieval Christianity. In the early twentiethcentury world of collector Cecil Sharp, folk music was considered as specific to a particular nation, hence 'its fitness to serve a national purpose follow[ed] as a natural consequence' (Sharp, 1907, x). Thus the children of England, by imbibing English folk song from an early age, would grow up 'naturally' English:

Folk-song is in verity the product of the people, rising as naturally out of its consciousness, expressing as truly its feelings and its aspirations, as the song of thrush and blackbird and ousel expresses the longings of the little hearts, and their rapture in spring sun and zephyrs (Sharp and BaringGould, ca. 1906, iii).

Alternatively, in D'Arcens's essay, music and literature are offered as evidence of - and as metaphors for - the

deep and complicated intertwining of these apparently opposed cultures ['East and West'] across hundreds of years. The task in reading Boussole is 
to refrain from turning Franz's fugue into plainchant. The contradictions, blind spots, and discomforts of this narrator are the novel's point.

In the light of this comparison, 'plainchant' distinctions like Sharp's and BaringGould's analogies can perhaps be seen as endeavours to dismiss the kinds of 'contradictions, blind spots, and discomforts' which Franz's 'wakeful ruminations' engender: those discomforts 'in which desire, denial, fascination, guilt, and the weight of history all move in counterpoint.' Nationalist rhetoric which excludes all voices but our own is one way to shut out 'desire, denial, fascination, guilt, and the weight of history,' but it seems, if possible, only to increase the offence when music is conscripted in that attempt.

\section{Time written on space}

Questions of identity are also posed in temporal terms; they have to be for an identity to be maintained through time. The loosely defined 'medieval,' our temporal other, standing in as both opposed to modernity and as its foundation, cannot choose but be caught up in these attempts. The medieval encompasses both continuity and rupture with the present, whenever 'the present' is situated. In Lynch's essay, 'last minstrels' inhabit a tangled temporality:

As the conduit of an imagined, loosely 'medieval,' past, the modern poetas-minstrel asserts long-term cultural continuity, or at least creates possibilities of rapprochement with that past. Yet in the guise of 'aged' and 'last' minstrels, archaic survivors in a latter age, modern poets both assert a 'medieval' identity for themselves and their work and acknowledge the impossibility of realizing that identity when the past has already gone.

In Upton's essay, the strategy of how we hold the medieval in the present is different. Bob Dylan enacts the medievalist entangling of time by framing his song narrative of late twentieth-century meetings and partings as a medieval ballade. In 'Tangled Up in Blue', Dylan 'def[ies] time,' eliminating it by turning it into space and stretching identity across it, trying

to be somebody in the present time, while conjuring up a lot of past images [...] I wanted to defy time, so that the story took place in the present and the past at the same time. When you look at a painting, you can see any part of it, or see all of it together. I wanted that song to be like a painting (Quoted in Heylin, 2001, 370).

There seems no possibility of ever settling the question of our identity in relation to the medieval when the term itself carries the same ambiguity. The 'medieval' has gone beyond recapture yet it remains and cannot be banished. Whether asserted or disavowed, as D'Arcens recognizes in her essay, the past remains, as 
3 Lynch lists some of the musical 'notes' in Scott's Lay:

" "Sound," in "voice," "clang,"

"din," "clash,"

"murmur,"

“mutter," "yell,"

"cry," "moan" and

"shrill," is a constant presence.' the temporal 'Other within the self' of the modern, and it takes different shapes. The past has different modes according to how it is approached, as Lynch's essay demonstrates. In music, as in imaginative literature, historical change is inflected by aesthetic and emotional responses in 'the [...] layering of time that both a sense of place and reading from the past create in the experience of individual subjects':

Yet at the same time as [Walter] Scott emphasizes the historical changes in religious culture, social organization, manners, and tastes that have made romance archaic, he suggests its power survives still in imaginative literature, according to a poetic timeline that constructs history along lines of aesthetic pleasure and emotional allegiance, through which modern subjects can still feel close to the heart of the past.

In Scott's Lay of the Last Minstrel, poetry (in which we can include music, not literally heard but made present to us through the 'soundscape' created by words) does not 'provide an authentic history, or undo historical change." 3 Nonetheless it can allow us 'new alignments with the past over the course of time' by 'attention to its creative performance.' As in music, passages of turmoil and enmity may find a degree of resolution through changes of key or peaceoffering cadences. In D'Arcens's essay a 'cadence' of words is chosen to end Boussole, with Franz 'thinking at dawn of the Danube, flowing between the two compass points [East and West], and realizing, finally, that it's "not shameful to give in $[\ldots]$ to the warm sunlight of hope."

Time is also written onto spaces, reversing Dylan's strategy in 'Tangled Up in Blue,' where he paints space onto time so he can 'see all of it together.' John M. Ganim has suggested that 'geography is transmuted into history,' as instanced in Raymond Schwab's statement that 'India was an "antiquity of today"' (Ganim, $2005,7)$. Temporal tricks are the mainstay of medievalism. Some countries are still 'medieval' according to certain sources. In the language of the early twentieth-century folklorists cited in my essay, certain 'races' remain 'in a state of arrested progress while others develop a highly-organized civilization' (Burne, 1914, 3). Some appear to do both at once, like Timothy Lynch's 'technologically sophisticated band of medieval barbarians [who] have declared war on America' (quoted in Holsinger, 2007, 8). Quite a degree of mental agility is required to strip technological sophistication of its typical associations with civilized modernity. But when an ethnic or national identity is forged on notions of superiority, that agility will be found.

In my essay, the nationalist anxieties evident in music revival rhetoric forbid any mingling of foreign influences with the 'purity' of English folk song or of English practices in the performance of medieval music, as opposed to those of continental Europe. But purity is also a temporal matter, since to remain so it must be maintained over time, as I write in my essay: 
Lineage - a pedigree - paper[s] over with words the impossibility of regimenting the past to uphold a chosen identity. In the English medieval and folk music revivals, music and its performance are harnessed in an attempt to maintain Englishness as an intrinsic and constant quality, superior, in its unassuming way, to other national types.

'Tradition', the unbroken chain linking the present with the past, is invoked to construct and maintain a straight and continuous line through time, keeping secure a chosen identity.

The past is differently experienced yet again within what D'Arcens calls 'the fugue-like structure' of the narrator Franz's 'wakeful ruminations,' where

this premodern time-place is best thought of as contrapuntal to Western modernity, a line entering, leaving and re-entering, running beneath and breaking across the main line in a kind of echoic structure. This contrapuntal relationship is witnessed in Franz's identification of what he regards as narrative patterns across centuries of Eastern verse romance and Western music.

Here again, 'geography is transmuted into history' as it is in fugue - in both musical and narrative patterns - an indication of how well music figures the spatio-temporal nature of medievalism, as D'Arcens's lines here enact. ${ }^{4}$ In this 'contrapuntal relationship [that] render[s] legends rhizomatic, their root systems horizontal and entangled,' any idea of a pure textual or musical inheritance resting on an unbroken national tradition is as unsustainable as the claim of 'pure' lineage exemplified by the family tree. ${ }^{5}$

\section{Conclusion}

Music and literature appear to offer but, when studied more closely, actually disrupt the comfortable distinctions on which, for many of us, a clear sense of identity relies. One could say that any identity is necessarily fugal, pieced together from different strands and patterns, or, to put it materially, it is like shot silk, 'a fabric which is made up of silk woven from warp and weft yarns of two or more colours producing an iridescent appearance' (Takeda and Spilker, 2010, 49). And the present is shot through with the past - with many pasts, just as any identity, whether personal, familial, national, ethnic, or religious, is shot through with countless and changing others. As Walt Whitman wrote, we contradict ourselves: 'Do I contradict myself? / Very well then I contradict myself, / (I am large, I contain multitudes.)' (Whitman, 2015, 83). How is it possible to pinpoint and maintain a sense of self under the weight of these multitudinous influences? Music can be seen as a promising yet ultimately disappointing resource in that endeavour.
4 Perhaps the psychological term 'dissociative fugue,' a form of amnesia in which identity is threatened, is also relevant here.

5 See Deleuze and Guattari (1988, 3-28) for the idea of a rhizome as opposed to a tree. For instance, '[A]ny point of a rhizome can be connected to anything other, and must be. This is very different from the tree or root, which plots a point, fixes an order [proceeding] by dichotomy' (7). 
6 See the

introduction and the three essays on music in the final section of Fugelso (2018). See the entire volume for a range of essays on the question of authenticity in medievalism.
If the 'medieval' of medievalism contains such a multitude of contradictions, it seems an unlikely supporter of identity, only to be sustained by cherry-picking on a massive scale - at least, that is, on the basis that identity is equated with unity or sameness. When identity is based on lineage, as in my essay, the past must be fossilized, corralled to stay forever in place, at least for those branded 'restorative' nostalgics by Svetlana Boym (and we may all be more 'restorative' than we know):

Restoration [...] signifies a return to the original stasis, to the prelapsarian moment. The past for the restorative nostalgic is a value for the present; the past is not a duration but a perfect snapshot. [...] Reflective nostalgia is more concerned with historical and individual time. [...] Restorative nostalgia takes itself dead seriously. Reflective nostalgia, on the other hand, can be ironic and humorous (Boym, 2001, 49).

'Dead' is the operative word here. Like the 'perfect snapshot,' the past - as guarantor of one's identity - is not supposed to move about, but it nonetheless refuses to lie down and die. How could it do otherwise when the emotional baggage of so many is bound up in it? In fact the term 'medievalism' itself, with its connotations of mobility and playfulness, would need to be proscribed for a true 'restorative.'

Perhaps, to pursue this idea a little further, the multiplicity of the 'medieval' suggests that if a pure and stable lineage is essential to the forging and maintenance of an identity - individual or group - then anxiety will be an intrinsic aspect of medievalism for many. The licence taken by the more freewheeling 'reflectives' will be a constant irritant, as the popularity of the term 'authentic' in debates around the correct performance of medieval music bore witness. ${ }^{6}$ The required decorum of critical or academic debate might mask the open expression of aggression and anxiety. Similarly, it might be considered more decorous for readers to tactfully ignore their recognition of that anger and anxiety when not explicitly stated, but nonetheless we cannot be blind to it. And in many forums, of course, open derision is de rigueur.

We are often made aware of the ideologies in play in versions of the medieval in academic and non-academic circles. They are no less apparent in debates about medieval music and its performance. But if ideology is the armour then the living, feeling flesh of medievalism is emotion. Ideology speaks loudly but sometimes hides the pain of the flesh. The rancour apparent in debates about medieval music is one instance of the degree to which we cling to our own particular version of the authentic Middle Ages. It is as if the word 'authentic' is forced to bear the weight of our identity. To quote John Ganim, 'The Medieval, almost by the root of its terminology, has always been imagined by the West as both ourselves and something other than ourselves' (Ganim, 2005, 5). If this is 
so, as our essays sometimes suggest, then the impossibility of the term comes to mirror the breakdown of the illusion of an undivided self.

\section{About the Author}

Helen Dell's work on thirteenth-century trouvère song includes her Ph. $\mathrm{D}$. thesis on desire in French medieval song, published by Boydell and Brewer in 2008 as Desire by Gender and Genre in Trouvère Song. More recently, Helen's work has explored the links between music and death. In 2017, she co-edited a collection, Singing Death (Routledge), with Helen Hickey. Her main research work is divided between medieval song and medievalism (usually musical), and she has published a number of chapters and articles on both, including a chapter, 'Musical Medievalism and the Harmony of the Spheres', in The Cambridge Companion to Medievalism (2016), edited by Louise D'Arcens (E-mail: helendell@internode.on.net).

\section{References}

Barratt-Peacock, R. and R. Hagen. 2019. Medievalism and Metal Music Studies: Throwing Down the Gauntlet. Bingley, UK: Emerald Publishing.

Bildhauer, B. and A. Bernau, eds. 2009. Medieval Film. Manchester, UK: Manchester University Press.

Boym, S. The Future of Nostalgia. 2001. New York: Basic Books.

Burne, C. 1914. The Handbook of Folklore. London: Sidgwick and Jackson.

D’Arcens, L., ed. 2016. Cambridge Companion to Medievalism. Cambridge, UK: Cambridge University Press.

Deleuze, G. and F. Guattari. 1988. A Thousand Plateaus: Capitalism and Schizophrenia, trans. B. Massumi. London: Athlone Press.

Fugelso, K., ed. 2018. Studies in Medievalism: Authenticity, Medievalism, Music XXVI. Cambridge, UK: D.S. Brewer.

Ganim, J.M. 2005. Medievalism and Orientalism: Three Essays on Literature, Architecture and Cultural Identity. New York: Palgrave Macmillan.

Gorbman, C. 1987. Unheard Melodies: Narrative Film Music. Bloomington, IN: Indiana University Press.

Heylin, C. 2001. Bob Dylan: Behind the Shades Revisited. New York: Harper Collins.

Holsinger, B. 2007. Neomedievalism, Neoconservatism, and the War on Terror. Chicago, IL: Prickly Paradigm.

Matthews, D. 2018. In Search of Lost Feeling: The Emotional History of Medievalism. Exemplaria 30(3): 207-22. 
Meyer, S.C. and K. Yri, eds. forthcoming 2019. Oxford Handbook on Music and Medievalism. Oxford, UK: Oxford University Press.

Pugh, T. and A. J. Weisl. 2013. Medievalisms: Making the Past in the Present. New York: Routledge.

Sharp, C. 1907. English Folk-song: Some Conclusions. London: Simpkin \& Co.; Novello \& Co.

Sharp, C. and S. Baring-Gould. ca. 1906. English Folk-Songs for Schools. London: Curwen.

Silvia, P.J. 2009. Looking Past Pleasure: Anger, Confusion, Disgust, Pride, Surprise, and Other Unusual Aesthetic Emotions. Psychology of Aesthetics, Creativity, and the Arts 3(1): 48-51.

Takeda, S.S. and K.D. Spilker. 2010. Fashioning Fashion: European Dress in Detail, 1700 to 1915. Munich, Germany: Delmonico Books.

Whitman, W. 2015. Song of Myself. In Leaves of Grass. San Diego, CA: Word Cloud Classics.

Young, H., ed. 2015. The Middle Ages in Popular Culture: Medievalism and Genre. Amherst, NY: Cambria Press.

Publisher's Note Springer Nature remains neutral with regard to jurisdictional claims in published maps and institutional affiliations. 